\title{
The Activity of Combination of Hydrolyzed Virgin Coconut Oil And Chitosan Toward Wound Healing Parameters on NIH 3T3 Cells Using In Vitro Methods
}

\section{Sipayung Hekdin Marsius ${ }^{1 *}$, Silalahi Jansen ${ }^{2}$, Yuandani1}

${ }^{1}$ Department of Pharmacology, Faculty of Pharmacy, University of Sumatera Utara, Medan, Indonesia.

${ }^{2}$ Department of Pharmaceutical Chemistry, Faculty of Pharmacy, University of Sumatera Utara, Medan, Indonesia.

\section{A B S T R A C T}

Objectives: The objective of this study was to investigate the activity of cell proliferation of Hydrolyzed Virgin Coconut Oil (HVCO) and chitosan. HVCO and chitosan concentrations with the highest cell viability were called the best concentrations. The best concentrations of Hydrolyzed Virgin Coconut Oil (HVCO) and chitosan were combined to determine NIH 3T3 cell migration, COX-2 and VEGF protein expression.

Design In vitro cell proliferation assay was determined by MTT (Microculture Tetrazolium Technique) assay, cell proliferation activity was measured by calculating cell viability incubated 24 hours, wound closure percentage was tested by scratch wound healing method, expression of COX-2 protein and VEGF protein were measured by immunocytochemical method. Interventions: The variable that was intervened in this study was the concentration of HVCO and chitosan.

Main Outcome Measures: The main measurements carried out in this study were the absorbance value of HVCO and chitosan which was converted into viability cell, proliferation activity, percentage of wound closure, and percentage of COX-2 and VEGF protein expression.

Results: Cell proliferation activity of $\mathrm{HVCO}$ and chitosan resulted the best concentration at $31.25 \mu \mathrm{g} / \mathrm{ml}$, scratch wound healing assay from the combination HVCO and chitosan resulted the best migration of fibroblast cells at ratio of 50:50 with HVCO $62.5 \mu \mathrm{g} / \mathrm{ml}$ and chitosan $62.5 \mu \mathrm{g} / \mathrm{ml}$. The combination of HVCO and chitosan (50:50) increased protein expression of COX-2 and VEGF.

Conclusion: Combination of HVCO and chitosan could increase NIH 3T3 cell migration, COX-2 and VEGF protein expression. Combination of HVCO and chitosan had better wound healing activity in vitro than single use.

Keywords: Rhizomucor miehei, viability, proliferation, migration, expression

\begin{tabular}{ll}
\hline A R T I C L E I N F 0: & Received 03 May 2019; Review Completed 29 May 2019; Accepted 07 June 2019; Available online 15 June 2019 \\
Cite this article as: \\
Sipayung H M , Silalahi J, Yuandani, The Activity of Combination of Hydrolyzed Virgin Coconut Oil and Chitosan \\
Toward Wound Healing Parameters on NIH 3T3 Cells Using In Vitro Methods, Asian Journal of Pharmaceutical \\
Research and Development. 2019; 7(3):14-19, DOI: http://dx.doi.org/10.22270/ajprd.v7i3.534
\end{tabular}

\section{INTRODUCTION}

$\mathrm{W}$ ounds are physical damage that results in the opening or rupture of the skin which causes disruption in the anatomy and function of normal skin ${ }^{1}$. Wound healing is an important physiological process to maintain the integrity of skin after trauma, either by accident or by intent procedure ${ }^{2}$. The process of wound healing is a biological process starting from the trauma and ending with the formation of scarring. Biological process consists of hemostasis, inflammation, proliferation and remodeling. Large numbers of cell types-including neutrophils, macrophages, limphocytes, keratinocytes, fibroblasts, and endothelial cells are involved in this process ${ }^{1-3}$. Macrophages play multiple roles in wound healing. In the early wound, macrophages release cytokines that promote the inflammatory response by recruiting and activating additional leukocytes ${ }^{1}$. One strategy to speed up the wound healing process is to combine HVCO and chitosan. HVCO contains free fatty acids and monoglycerides especially lauric acid and active monolaurin as antibacterial and antiviral agents ${ }^{4-5,8-9,15}$. Chitosan is a 
biopolymer resulting from the deacetylation process of chitin which can accelerate fibroblast formation and improve the initial phase reactions associated with wound healing ${ }^{6-7}$.

This study was aimed to determine the activity of combination of $\mathrm{HVCO}$ and chitosan toward wound healing parameters on NIH 3T3 cells using in vitro methods.

\section{MATERIALS AND METHODS}

VCO (Palem Mustika ${ }^{\circledR}$, Indonesia) was obtained from Guardian drug store, Chitosan was obtained and identified in Laboratory of Research Center of Faculty of Mathematics and Natural Science, University of Sumatera Utara, Medan, Indonesia. NIH 3T3 cells were obtained from department of parasitology, Faculty of Medicine, University of Gadjah Mada. Chemicals used were DMSO (Merck), [3-(4,5-dimethylthiazole-2-yl)-2,5-diphenyl tetrazolium bromide] (MTT) (Sigma), chromogen 3,3diaminobenzidin (DAB) (Novo Castra), monoclonal antibody COX-2 and VEGF.

\section{Enzymatic Hydrolysis of VCO}

About $30 \mathrm{~g}$ of oil was weighed into $250 \mathrm{ml}$ Erlenmeyer flask, and then $30 \mathrm{ml}$ distilled water, $12.5 \mathrm{ml} 0.063 \mathrm{M}$ $\mathrm{CaCl}_{2}, 25 \mathrm{ml}$ buffer Tris-HCl $1 \mathrm{M} \mathrm{pH} 8$, and $3 \mathrm{ml}$ lipase from Rhizomucor miehei were added into the flask. The mixture was incubated at $50^{\circ} \mathrm{C}$ and stirred at $200 \mathrm{rpm}$ for $10 \mathrm{~min}$ of every $1 \mathrm{~h}$ incubation time $(10 \mathrm{~h})$. At the end of incubation time, the mixture was transferred into the separating funnel, then $50 \mathrm{ml} \mathrm{n}$-hexane was added, and extraction was done. The mixture was allowed to stand for some time until two layers were formed. The upper layer (n-hexane fraction) was separated as the first filtrate, while the bottom layer (water fraction) was extracted again with $50 \mathrm{ml}$ of $\mathrm{n}$-hexane. The mixture was then allowed to stand for some time and the upper layer formed was separated as the second filtrate. The first and second filtrates were mixed, and then $250 \mathrm{~g}$ sodium sulfate anhydrous was added to absorb the water residue. The combined filtrate was allowed to stand for $15 \mathrm{~min}$, filtered, and the n-hexane was evaporated using the water bath to obtain hydrolyzed VCO (HVCO $)^{5-9}$.

\section{Acid Value Determination}

Five (5) g of HVCO was weighed and transferred into 250 ml Erlenmeyer flask. $25 \mathrm{~mL}$ of neutral ethanol $90 \%$ was added and then heated for $10 \mathrm{~min}$ in a water bath while being stirred, and then 3-5 drops of phenolphthalein were added into this solution. Titration was done with $0.1 \mathrm{~N}$ $\mathrm{NaOH}$ until the solution turned pink (color did not change for $15 \mathrm{~min}$ ). The acid value and free fatty acid (FFA) percentage of HVCO were calculated using the following equation $^{5-9}$.

Acid value $=\frac{\mathrm{A} \times \mathrm{N} \times \mathrm{MW} \mathrm{NaOH}}{G}$

Where,

$\mathrm{A}=\mathrm{NaOH}$ solution volume $(\mathrm{ml})$

$\mathrm{N}=$ Normality of $\mathrm{NaOH}$ solution

$\mathrm{G}=$ Sample mass $(\mathrm{g})$

Molecular Weight of $\mathrm{NaOH}=40 \mathrm{~g} / \mathrm{mol}$
Acid value expressed as $\mathrm{mg} \mathrm{NaOH} / \mathrm{g}$ oil was then converted to $\mathrm{mg} \mathrm{KOH} / \mathrm{g}$ oil.

\section{Preparation of HVCO}

HVCO was weighed $10 \mathrm{mg}$ in the politube and dissolved in dimethylsulfoxide (DMSO) $100 \mu \mathrm{L}$. The sample was vortexed to dissolve completely then added with DMEM culture medium and diluted until the test solution was obtained with a concentration of $500 \mu \mathrm{g} / \mathrm{ml} ; 250 \mu \mathrm{g} / \mathrm{ml}$; $125 \mu \mathrm{g} / \mathrm{ml} ; 62.5 \mu \mathrm{g} / \mathrm{ml}, 31.25 \mu \mathrm{g} / \mathrm{ml}$ and $15.625 \mu \mathrm{g} / \mathrm{ml}$; all dilutions were carried out using DMEM medium containing $10 \%$ Fetal Bovine Serum (Gibco), $1 \%$ penicillin-streptomycin (Gibco), and fungizone $0.5 \%$ $(\text { Gibco })^{10}$.

\section{Preparation of Chitosan}

Chitosan was weighed $10 \mathrm{mg}$ in the politube and dissolved in dimethylsulfoxide (DMSO) $100 \mu \mathrm{L}$. The sample was vortexed to dissolve completely then added with DMEM culture medium and diluted until the test solution was obtained with a concentration of $500 \mu \mathrm{g} / \mathrm{ml}$; $250 \mu \mathrm{g} / \mathrm{ml} ; 125 \mu \mathrm{g} / \mathrm{ml} ; 62.5 \mu \mathrm{g} / \mathrm{ml}, 31.25 \mu \mathrm{g} / \mathrm{ml}$ and $15.625 \mu \mathrm{g} / \mathrm{ml}$; all dilutions were carried out using DMEM medium containing 10\% Fetal Bovine Serum (Gibco), $1 \%$ penicillin-streptomycin (Gibco), and fungizone $0.5 \%$ (Gibco) ${ }^{10}$.

\section{Proliverative Activity}

Proliferation activity assay was carried out at the optimal concentration of HVCO and chitosan from the cell viability test. NIH 3 T3 cells $\left(1 \mathrm{x} 10^{4}\right.$ cells/well) were planted in MK DMEM, and added $100 \mu \mathrm{L}$ test solution. After incubation for 24, 48 and 72 hours, MTT assay was performed on each well, added $100 \mu \mathrm{L}$ of culture media and $10 \mu \mathrm{L}$ of MTT (Sigma) $5 \mathrm{mg} / \mathrm{mL}$. Cells were reincubated for $4-6$ hours in a $5 \% \mathrm{CO}_{2}$ incubator, $37^{\circ} \mathrm{C}$. The MTT reaction was stopped with a reagent stopper $(10 \%$ SDS in $0.01 \mathrm{~N} \mathrm{HCl}$ ), wrapped plate left for one night. Absorbance was measured using Elisa Reader (Biorad) at a wavelength of $595 \mathrm{~nm}$. This test is done with replication 3 times (triplo) ${ }^{10,13}$.

\section{Scratch assay}

The migration test for the combination of HVCO and chitosan was carried out by making 5 series comparisons of the concentration with the highest prolifersion activity in HVCO and chitosan. Comparison of HVCO and chitosan concentrations used is $100: 0 ; 75: 25 ; 50 ; 50$; 25:75; and 0: 100 from each effective concentration. Cell migration testing was carried out on NIH 3T3 cells planted in microplate 24 wells with a number of cells $5 \mathrm{x}$ $10^{4}$ cells / well, each well $500 \mu \mathrm{l}$ and incubated for 24 hours at $37^{\circ} \mathrm{C}$. Cell cultures were washed with PBS and replaced medium with $0.5 \%$ Fetal Bovine Serum and incubated for 24 hours. Scratches were made on the bottom surface of the well using a yellow tip tip. The old media was discarded and washed in a well with $500 \mu 1$ PBS and taken from each group by using an inverted microscope. PBS was removed from the well by being pipetted slowly and then put the test solution $500 \mu \mathrm{L}$, incubated for 72 hours at $37^{\circ} \mathrm{C}$. Cell conditions were observed after incubation of $0,24,48$, and 72 hours. Microscopic images were moved in JPEG format. The initial pixel distance with an empty pixel area was 
measured using Image $\mathbf{J}$ software. This test was done with replication 3 times (triplo) ${ }^{10,13}$. The percentage was calculated by the formula:

Scratch $=100 \%-\left\{\frac{\text { (blank pixel area) }}{\text { (initial scratch pixel) }}\right\} \times 100 \%$

\section{Immunocytochemistry}

NIH 3 T3 cells $\left(1 \times 10^{5}\right.$ cells/well $)$ were seeded on coverslips in 24-well plate and incubated for 24 hours. After that, the cells were treated with combination of HVCO and chitosan and then incubated for 24 hours. After incubation, the cells were washed with PBS and then fixed with cold methanol for 10 minutes then the cells were washed with PBS and blocked in hydrogen peroxide blocking solution for 10 minutes at room temperature, incubated using primary antibody COX-2 and VEGF for 1 hour, then washed twice with PBS, then incubated with secondary antibody for 10 minutes. The cells were washed with PBS, then incubated in 3,3diaminobenzidine (DAB) solution for 10 minutes, and washed with distilled water. Afterwards, the cells were drowned with Mayer-Haematoxylin for 10 minutes, and washed with distilled water. The cover slips were taken from each well using nippers, then placed on a glass object, added with absolute ethanol, and dried. After that, added xylol and dried, then added entellan and covered with coverslip. COX-2 and VEGF expressions were observed using a light microscope with an optical camera using Raster Image Software ${ }^{10,} 11,{ }^{14}$. The number of protein expressions was calculated by the formula:

$\%$ protein expressions $=\frac{\text { Number of cells expressed }}{\text { Total cell count }} \times 100 \%$

\section{Statistical analysis}

The data was presented as the mean \pm standard error of mean (SEM). The normality of all the data was first determined by Shapiro-Wilk test. Statistical differences were determined using one-way analysis of variance (ANOVA) followed by Tukey HSD post hoc test. A value of $p<0.05$ was considered to be significant. All analysis were performed using SPSS software version 22.0

\section{RESULTS AND DISCUSSION}

\section{Acid Value}

Enzymatic hydrolysis of VCO (virgin coconut oil) was carried out using Rhizomucor miehei, incubated at $50^{\circ} \mathrm{C}$, $\mathrm{pH} \mathrm{8,} \mathrm{for} 10$ hours. Rhizomucor miehei hydrolyzed fatty acids of virgin coconut oil at the position of sn- 1 and sn-3 in triglyceride molecules which produced two free fatty acids (FFA) and 2-monoglycerides ${ }^{9,15}$.

Table 1: Acid value of VCO and HVCO

\begin{tabular}{|l|l|}
\hline \multicolumn{1}{|c|}{ Sample } & \multicolumn{1}{|c|}{ Acid value $(\mathrm{mg} \mathrm{KOH} / \mathrm{g}$ oil $) \mathrm{n}=3$} \\
\hline VCO & $1.360 \pm 0.315$ \\
\hline HVCO & $133.552 \pm 0.610$ \\
\hline
\end{tabular}

\section{Proliferation Activity}

Proliferation is one phase in healing wounds. The proliferation phase is the phase where the fibrin matrix enters the wound area, stimulates growth factor, extracellular matrix, and angiogenesis which plays a role in the wound healing process 16 .

\section{Proliferation Activity of HVCO and chitosan}

HVCO and chitosan was investigated for its proliferation activity on NIH 3T3 cell lines. Viability of NIH 3T3 cells was measured using the MTT method. The absorbance data obtained from each concentration of the test material was converted to percent cell viability which was carried out three times.

Table 2: NIH 3 T3 cell proliferation activity in various concentration of test material at 24 hours incubation

\begin{tabular}{|c|c|c|}
\hline Treatment & $\begin{array}{c}\text { Concentration } \\
(\mu \mathrm{g} / \mathrm{ml}) \mathrm{n}=\mathbf{3}\end{array}$ & $\begin{array}{c}\text { Cell viability }(\%) \\
(\text { Mean } \pm \text { SEM) } n=3\end{array}$ \\
\hline Cell control & & $100.00 \pm 0.00$ \\
\hline \multirow[t]{6}{*}{ HVCO } & 500 & $0.47 \pm 1.05^{*}$ \\
\hline & 250 & $22.35 \pm 3.73^{*}$ \\
\hline & 125 & $132.53 \pm 5.29^{\#}$ \\
\hline & 62.5 & $148.63 \pm 6.06^{*}$ \\
\hline & 31.25 & $151.16 \pm 5.92 *$ \\
\hline & 15.625 & $86.22 \pm 4.28^{\#}$ \\
\hline \multirow[t]{6}{*}{ Chitosan } & 500 & $86.90 \pm 6.24^{\#}$ \\
\hline & 250 & $97.78 \pm 9.90^{\#}$ \\
\hline & 125 & $102.14 \pm 7.17^{\#}$ \\
\hline & 62.5 & $105.88 \pm 8.41^{\#}$ \\
\hline & 31.25 & $124.06 \pm 4.69^{\#}$ \\
\hline & 15.625 & $96.79 \pm 1.55^{\#}$ \\
\hline \multirow[t]{6}{*}{ VCO } & 500 & $125.28 \pm 9.38^{\#}$ \\
\hline & 250 & $129.54 \pm 9.40^{\#}$ \\
\hline & 125 & $143.83 \pm 8.93^{\#}$ \\
\hline & 62.5 & $139.70 \pm 7.27^{\#}$ \\
\hline & 31.25 & $137.95 \pm 7.83^{\#}$ \\
\hline & 15.625 & $91.43 \pm 4.46^{\#}$ \\
\hline
\end{tabular}

${ }^{*} p<0.05$ : there are significant differences with cell control ${ }^{\#} p>0.05$ : there are no significant differences with cell control

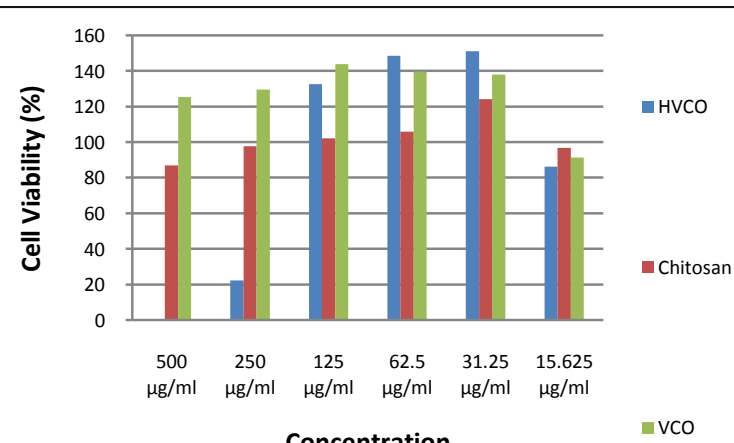

Concentration

Figure 1: Percentage of viability of NIH 3 T3 cell to the sample 


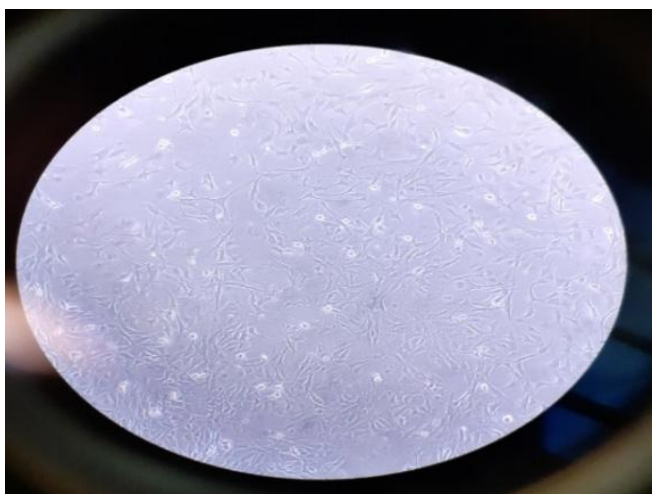

Figure 2: NIH 3T3 cell

The highest percentage of viability of NIH 3T3 cells from HVCO found at concentrations of $31.25 \mu \mathrm{g} / \mathrm{ml}$ and chitosan was found at a concentration of $31.25 \mu \mathrm{g} / \mathrm{ml}$. The best viability of NIH 3T3 cells from HVCO and chitosan will be continued to the cell migration test.

Lauric acid and monolaurin are antibacterial and antiinflammatory agents that can heal wounds. Lauric acid and monolaurin can reduce the time for complete epithelialization, because lauric acid and monolaurin can increase cell proliferation and cell migration. The combination of these two components is synergistic as antibacterial and antiviral so that it can cure wound infections especially burns ${ }^{5,7}$.

Chitosan provides a tissue growth matrix, activates macrophage activity and stimulates cell proliferation. Chitosan will stimulate proliferation of fibroblasts, helping to accumulate collagen regularly to stimulate the

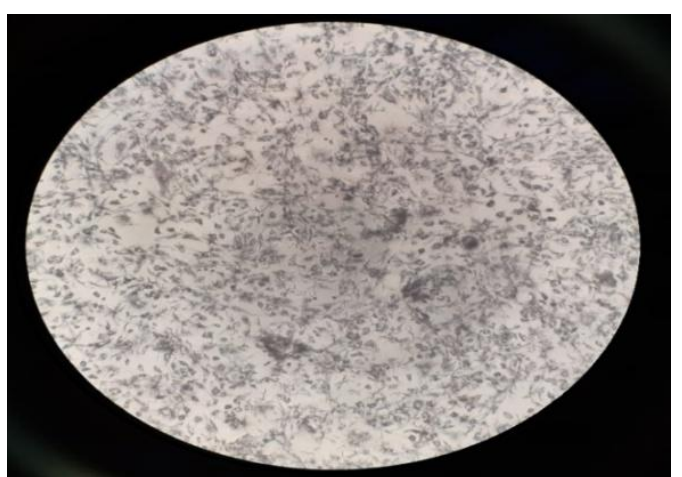

Figure 3: Formazan crystals

synthesis of hyaluronic acid at the site of the wound. This speeds up the healing process and prevents scar formation $^{17,18}$.

The highest proliferation activity of $3 \mathrm{~T} 3 \mathrm{NIH}$ cells was found at concentration $31.25 \mu \mathrm{g} / \mathrm{ml}$ for 24 hours incubation. HVCO $31.25 \mu \mathrm{g} / \mathrm{ml}$ and chitosan $31.25 \mu \mathrm{g} / \mathrm{ml}$ at incubation for 24 hours had a percentage of cell viability of $151.16 \pm 5.92$ and $124.06 \pm 4.69$.

\section{Scratch assay}

Migration of 3T3 NIH cells was determined by the in vitro scratch assay method which was observed at 24,48 and 72 hours after treatment. The HVCO and chitosan concentrations used for single were $31.25 \mu \mathrm{g} / \mathrm{ml}$, while for the combination used the concentration of $62.5 \mu \mathrm{g} / \mathrm{ml}$ so that when combined with HVCO and chitosan the same concentration with a single concentration was obtained which was the optimal concentration.

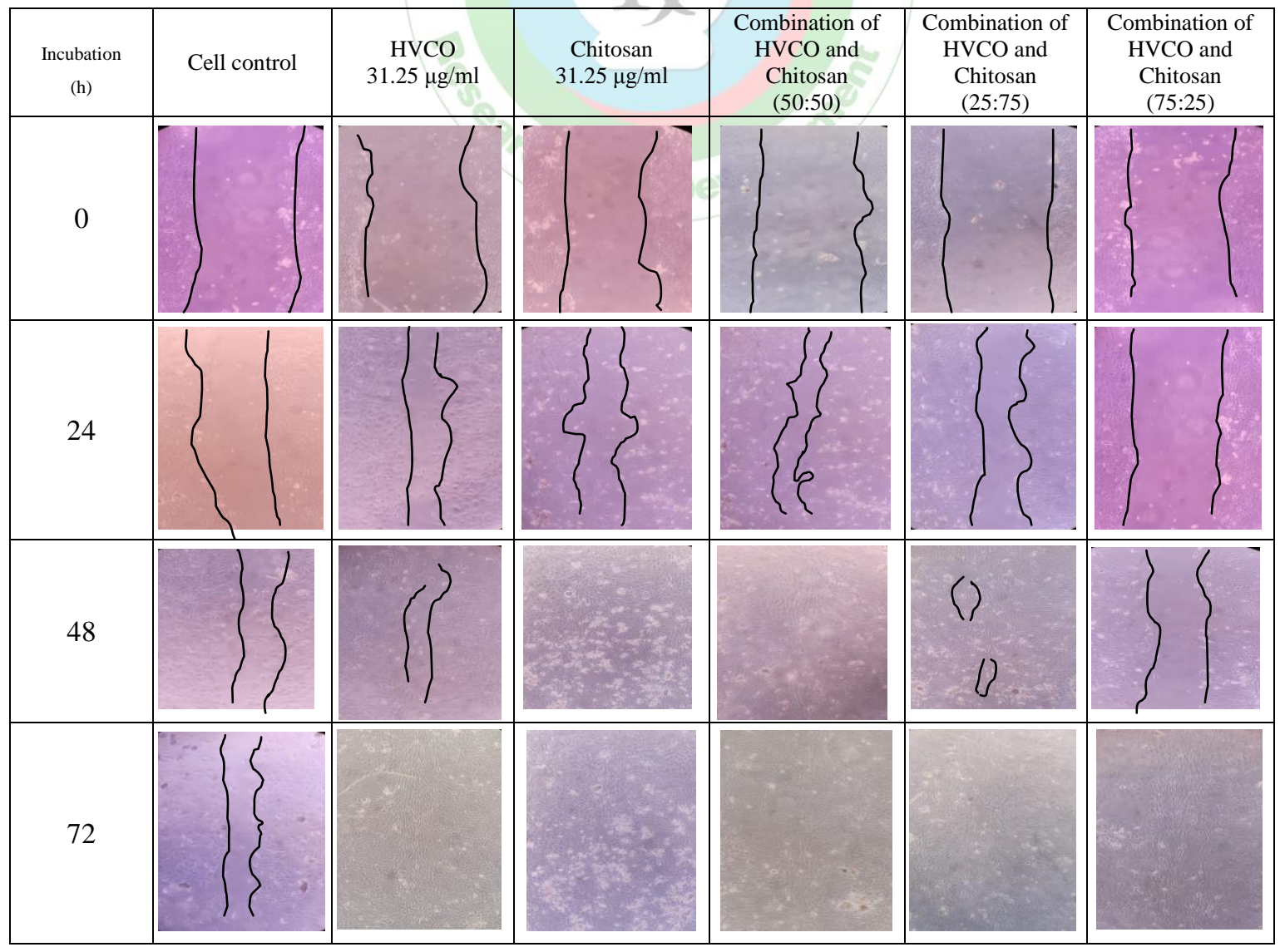

Figure 4: Activity of wound closure of NIH 3T3 cells treated with HVCO, Chitosan and Combination of HVCO and Chitosan(50:50); (25:75); (75:25) at incubation $0 ; 24 ; 48 ; 72$ hours by measuring the area of wound closure 
Table 3: Percentage of wound closure after therapy

\begin{tabular}{|c|c|c|c|}
\hline \multirow[t]{2}{*}{ Treatment } & $\begin{array}{l}\text { Wound closure }(\%) \\
(\text { Mean } \pm \text { SEM })\end{array}$ & $\begin{array}{l}\text { Wound closure }(\%) \\
(\text { Mean } \pm \text { SEM })\end{array}$ & $\begin{array}{l}\text { Wound closure }(\%) \\
(\text { Mean } \pm \text { SEM })\end{array}$ \\
\hline & 24 jam & 48 jam & $72 \mathrm{Jam}$ \\
\hline Cell control & $25.67 \pm 0.11$ & $63.70 \pm 0.03$ & $66.81 \pm 0.07$ \\
\hline HVCO $31.25 \mu \mathrm{g} / \mathrm{ml}$ & $60.08 \pm 0.06^{*}$ & $97.59 \pm 0.02 *$ & $100.00 \pm 0.00^{*}$ \\
\hline Chitosan $31.25 \mu \mathrm{g} / \mathrm{ml}$ & $56.88 \pm 0.05^{*}$ & $97.41 \pm 0.03 *$ & $100.00 \pm 0.00^{*}$ \\
\hline $\begin{array}{l}\text { Combination of HVCO and Chitosan } \\
(50: 50)\end{array}$ & $86.30 \pm 0.00 *$ & $100.00 \pm 0.00 *$ & $100.00 \pm 0.00^{*}$ \\
\hline $\begin{array}{l}\text { Combination of } \mathrm{HVCO} \text { and Chitosan } \\
(25: 75)\end{array}$ & $53.45 \pm 0.04 *$ & $93.73 \pm 0.00^{*}$ & $100.00 \pm 0.00^{*}$ \\
\hline $\begin{array}{llll}\text { Combination } & \text { of } & \text { HVCO } & \text { and } \\
\text { Chitosan }(75: 25) & & & \end{array}$ & $7.04 \pm 0.07 *$ & $45.37 \pm 0.02 *$ & $100.00 \pm 0.00^{*}$ \\
\hline
\end{tabular}

Post Hoc Tukey test,$\alpha<0.05)$

$*_{\mathrm{p}}<0.05$ : there are significant differences with cell control

Combination of HVCO and chitosan(50:50) has the highest percentage of wound closure $(86.30 \%$ after 24 hours incubation, and $100 \%$ after 48 hours incubation). This combination is the best test material in the wound closure process.During the wound healing process, the cells on the wound edge proliferate and migrate, causing re-epithelialization of the wound surface. Lauric acid and monolaurin can increase cell proliferation and cell migration. Chitosan provides a tissue growth matrix, activates macrophage activity and stimulates cell proliferation. Chitosan increases the activity of polymorphonuclear leukocytes, macrophages and fibroblasts which will improve the granulation and tissue regulation. Chitosan has biological activities such as wound healing, antimicrobials, hemostasis, and tissue regeneration $^{5,17-19}$.

\section{Immunocytochemistry}

Immunocytochemistry is a method used to detect COX-2 and VEGF protein expression in NIH $3 \mathrm{~T} 3$ cells ${ }^{10}$.

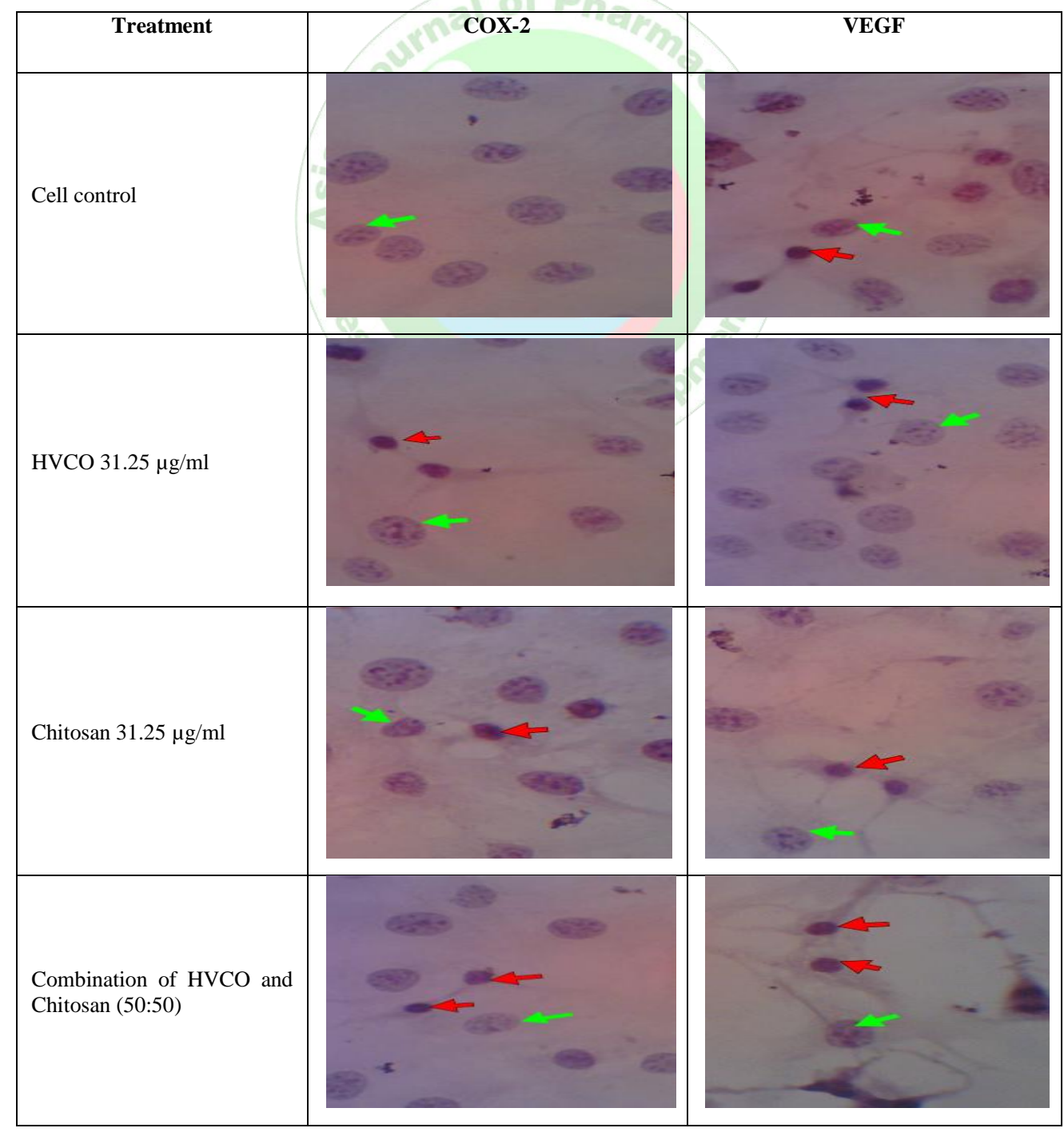

Figure 5: COX-2 and VEGF protein expression in NIH $3 \mathrm{~T} 3$ cells after therapy

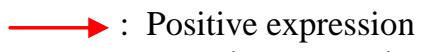

$\longrightarrow$ : Negative expression 
Table 4: Expression of COX-2 and VEGF after therapy

\begin{tabular}{|l|l|l|}
\hline \multirow{2}{*}{ Treatment } & \multicolumn{2}{c|}{$\begin{array}{c}\text { Protein expression (\%) } \\
\text { (Mean } \pm \text { SEM) }\end{array}$} \\
\cline { 2 - 3 } & \multicolumn{1}{|c|}{ COX-2 } & \multicolumn{1}{c|}{ VEGF } \\
\hline Cell control & $16.31 \pm 0,32$ & $17.89 \pm 0.19$ \\
\hline HVCO $31.25 \mu \mathrm{g} / \mathrm{ml}$ & $30.02 \pm 0,25^{*}$ & $27.26 \pm 0.21^{*}$ \\
\hline Chitosan $31.25 \mu \mathrm{g} / \mathrm{ml}$ & $27.90 \pm 0,18^{*}$ & $27.17 \pm 0.29^{*}$ \\
\hline Combination of $\mathrm{HVCO}$ and Chitosan $(50: 50)$ & $45.63 \pm 0,24^{*}$ & $35.77 \pm 0.16^{*}$ \\
\hline
\end{tabular}

Post_Hoc Tukey test, $\alpha<0.05$ )

$*_{\mathrm{p}}<0.05$ : there are significant differences with cell control

The combination of HVCO and chitosan (50:50) were stronger in stimulating COX-2 and VEGF expression and thus played a faster role in the wound healing process. COX-2 plays a key role in regulating VEGF production in fibroblasts. VEGF stimulates angiogenesis in the process of repairing wounds ${ }^{20}$.

Lauric acid, monolaurine found in HVCO and chitosan increase COX-2 and VEGF expression which mediates angiogenesis and NIH 3T3 cell migration. The combination of HVCO and chitosan (50:50) was able to improve the parameters in this study namely cell proliferation activity, scratch wound healing, and COX-2 and VEGF expression. Increasing these parameters affects the factors that play a role in wound healing.

\section{REFERENCES}

1. Guo S, DiPietro LA. Factors Affecting Wound Healing. Journal of Dental Research. 2010; 89(3): 219-29.

2. Wang PH, Huang BS, Horng HC, Yeh CC, Chen YJ. Wound Healing. Journal of the Chinese Medical Association. 2018; 81: 94101.

3. Soliman AM, Lin TS, Ghafar NA, Das S. Virgin Coconut Oil and Diabetic Wound Healing: Histopathological and Biochemical Analysis. European Journal of Anatomy. 2018; 22(2):135-44.

4. Lieberman S, Enig MG, Preuss HG. A Review of Monolaurin and Lauric Acid Natural Virucidal and Bactericidal Agent. Alternative \& Complementary Therapies. 2006; 12(6):310-314.

5. Silalahi J, Surbakti C. Burn Wound Healing Activity of Hydrolyzed Virgin Coconut Oil. International Journal of Pharma Tech Research. 2015; 8(1):67-73.

6. Silalahi J, Permata YM, Putra ED. Antibacterial Activity of Hydrolyzed Virgin Coconut Oil. Asian Journal Pharmaceutical and Clinical Research. 2014; 7(2):90-4.

7. Silalahi J, Situmorang P, Patilaya P, Silalahi YC. Antibacterial Activity of Chitosan and Hydrolized Coconut Oil and Their Combination against Bacillus cereus and Escherichia coli. Asian Journal of Pharmaceutical and Clinical Research. 2016; 9(5): 69-73.

8. Loung FS, Silalahi J, Suryanto D. Antibacterial Activity of Enzymatic Hydrolized of Virgin Coconut Oil and Palm Kernel Oil Against Staphylococcus aureus, Salmonella thypii and Escherichia coli. International Journal of PharmaTech Research. 2014; 6:628-33.

9. Margata L, Silalahi J, Harahap U, Satria D. The Effect of Dietary Oils and Hydrolyzed Coconut Oil on Minerals Absorption in Rats. Asian Journal Pharmaceutical and Clinical Research. 2018; 11:18590.

10. Cancer Chemoprevention Research Center. Fixed Procedure of Sample Preparation. Faculty of Pharmacy, University of Gadjah Mada; 2009. p. 1-3.

11. Satria D, Silalahi J, Haro G, Ilyas S, Hasibuan PAZ.Cell Cycle Inhibition of Ethylacetate Fraction of Zanthoxylum Acanthopodium

\section{CONCLUSION}

Based on the results we obtain combination of HVCO and chitosan (50:50) could increase NIH 3T3 cell migration, COX-2 and VEGF protein expression. Combination of $\mathrm{HVCO}$ and chitosan had better wound healing activity in vitro than single use.

\section{ACKNOWLEDGMENT}

The authors would like to thank BPPSDM (Badan Pengembangan dan Pemberdayaan Sumber Daya Manusia)-Ministry of Health of the Republic of Indonesia for the opportunity to obtain a postgraduate scholarship in 2017 at the University of Sumatra Utara, Medan.

\section{CONFLICTS OF INTEREST}

The authors declare that they have no conflicts of interest.

12. DC. Fruit against T47D Cells. Macedonian Journal of Medical Sciences. 2019; 7(5):726-29.

13. Hasibuan PAZ, Sumaiyah. The Anti-Proliferative and ProApoptotic Properties of Ethanol Plectranthusamboinicus (Lour.) Spreng. Leaves Ethanolic Extract Nanoparticles on T47D Cell Lines. Asian Pacific Journal of Cancer Prevention. 2019; 20(3):897-901

14. Harahap U, Hasibuan PAZ, Sitorus P, Arfian N, Satria D. Antimigration Activity of an Ethylacetate Fraction of Zanthoxylum acanthopodium DC. Fruits in 4T1 Breast Cancer Cells. Asian Pacific Journal of Cancer Prevention. 2018; 19(2):565-69.

15. Nugroho AE, Hermawan A, Putri DDP, Novika A, Meiyanto E. Combinational Effects of Hexane Insoluble Fraction of Ficusseptica Burm. F. and doxorubicin chemotherapy on T47D breast cancer cells. Asian Pacific Journal of Tropical Biomedicine. 2013; 3(4):297-302.

16. Dayrit FM. The Properties of Lauric Acid and Their Significance in Coconut Oil. Journal of the American Oil Chemists' Society. $2015 ; 92: 1-15$

17. Wild T, Rahbarnia A, Kellner M, Sobotka L. Basic in Nutrition and Wound Healing. Nutrition. 2015; 26:862-66.

18. Kim SK. Chitin, Chitosan, Oligosaccharides and Their Derivates: Biological Activities and Applications. CRC Press; 2011. p. 13, 461-73.

19. Cheung RCF, Ng TB, Wong JH, Chan WY. Chitosan: An Update On potential Biomedical and Pharmaceutical Aplications. Marine Drugs. 2015; 13:5156-86.

20. Nevin KG, Rajamohan T. Effect of Topical Application of Virgin Coconut Oil on Skin Components and Antioxidant Status during Dermal Wound Healing in Young Rats. Skin Pharmacology and Physiology. 2010; 23:290-97.

21. Miura S, Tatsuguchi A, Wada K, Takeyama H, Shinji Y, Hiratsuka T, Futagami S, Miyake K, Gudis K, Mizokami Y, Matsuoka T, Sakamoto C. Cyclooxygenase-2-Regulated Vascular Endothelial Growth Factor Release in Gastric Fibroblasts. American Journal of Physiology Gastrointestinal and Liver Physiology. 2004; 287:44451. 